\title{
Assessment of Soil Quality and Performance of Chickpea under Permanent Manurial Trial on Soybean-Chickpea Sequence in Rainfed Vertisols
}

\author{
P. Patidar, S.P.K. Unni*, S.K. Sharma and U.R. Khandkar
}

Department of Soil Science and Agricultural Chemistry, Rajmata Vijayaraje Scindia Krishi Vishwa Vidyalaya, Gwalior, College of Agriculture Indore (M. P.), India

*Corresponding author

\section{A B S T R A C T}

\section{Keywords}

Soil quality,

Chickpea, Manorial trial

Article Info

Accepted:

12 March 2018

Available Online:

10 April 2018
The present study is carried out in a permanent manurial trial (PMT), which is running since 1992 in Vertisols with the following specific objectives to assess soil quality under permanent manurial trial, to determine crop quality of rain fed chickpea as influenced by long term fertility treatments under PMT, to Study the growth and productivity of chickpea under PMT and to work out the economic viability of different fertility treatments.

\section{Introduction}

Chickpea (Cicer arietinum L.) is the premier pulse crop of Indian subcontinent. Chickpea probably originated in southeastern Turkey and spread west and south via the Silk Route. Four centers of diversity have been identified in the Mediterranean, Central Asia, the Near East and India, as well as a secondary center of origin in Ethiopia.

It is grown and consumed in large quantities from South East Asia to India and in the Middle East and Mediterranean countries. It ranks second in area and third in production among pulses worldwide. India is the largest chickpea producer as well as consumer in the world. India grows chickpea on about 6.67 million ha area producing 5.3 million tons which represents $30 \%$ and $38 \%$ of the national pulse acreage and production, respectively. Chickpea production has gone up from 3.65 to 5.63 million tons between 195051 and 2004-05, registering a growth of $0.58 \%$ annually. During the period, area has marginally declined from 7.57 to 6.67 million hectare and the productivity has steadily increased to $844 \mathrm{~kg} / \mathrm{ha}$ from $482 \mathrm{~kg} \mathrm{ha}^{-1}$. Notwithstanding its distribution throughout the country, six states viz., Madhya Pradesh, Rajasthan, Maharashtra, Uttar Pradesh, Karnataka and Andhra Pradesh together contribute $91 \%$ of the production and $90 \%$ of the area of the country. 
The use of high analysis fertilizer for immediate boosting of production potentials of crop plants cast the shadow on use of organic manures. This reflects on degradation of soil quality and environments as well as sustainability of yield levels of crop plants (Virmani et al., 1991). The genetic potential of different crop varieties is not changed. However, soil quality is the major functional factor in alteration of production potential of crops. To overcome this problem the integrated nutrient management system (INM) is adopted in cropping system. The basic concept of the INM is to maintain soil fertility for sustained crop productivity on long-term basis and also reduce fertilizer input cost. At present the quantity of inorganic fertilizers is reduced by substituting the various organic manures viz., FYM, vermi compost, green manuring and recycling of crop residues. The protection of environment and sustainability in yield levels can be achieved by the integrated nutrient management. This is the noble approach of organic farming.

Integrated nutrient management (INM) has shown its potential in increasing crop productivity may be due to the combined effect of nutrient supply, synergism and improvement in soil physical and biological properties and also in crop physiological processes. Therefore, it has realized that there is a need for an assessment on crop specific land quality so that the yield diminishing factors can be identified. The need for development of a land quality index with reference to type of land use was stressed by the World Bank (1995) and Karlen et al., (1997).

\section{Materials and Methods}

The present investigation entitled "Assessment of soil quality and performance of chickpea under permanent manurial trial on soybeanchickpea sequence in rainfed Vertisols" was carried out in Rabi season during the year 2011-12 under All India Coordinated Research Project for Dry land Agriculture, College of Agriculture, Indore in field No.19.

The details of material used and methodology adopted are given below. There were nine treatments and each of them were randomized and replicated three times. The design used in the experiment was randomized block design. Details of treatments

FYM was applied in prescribed treatments at the time of field preparation only. The requisite quantity of nitrogen and phosphorus were applied as basal dose at the time of sowing. Crop residues were applied in prescribed treatments as surface mulch after emergence of the crop and incorporated after harvesting of crop. Method of statistical analysis

The data were analyzed by method of analysis of variance as described by Fisher (1950). The structure of analysis of variance is given below. The design of experiment was simple randomized block design with three replications. The null hypothesis was tested by the " $F$ " test, which revealed the significance of treatment effects. The critical differences for treatment means was calculated by using equation given by Panse and Sukhatme (1967). The standard error of means and coefficient of variation were calculated from early mean square as follows:

\section{$\mathrm{SEm}+=\mathrm{EMS} / \mathrm{r}$}

C.D. $(5 \%)=\sqrt{ }$ SEm $\times 2 \times$ table " $t$ " value at $5 \%$ at 16 d.f.

\section{Results and Discussion}

The growth parameters of chickpea as influenced by various treatments are given in Table 1 with regard to plant height. 
Data on seed yield of chickpea due to different treatments of chickpea have been given in Table 2.

\section{Summary}

The present investigation entitled "Assessment of Soil Quality and Performance of Chickpea under Permanent Manurial Trial on SoybeanChickpea Sequence in Rainfed Vertisols" was carried out in Rabi season during the year 2011-12 under All India Coordinated Research Project for Dryland Agriculture, College of Agriculture, Indore. The details of material used and methodology adopted are given in present chapter. A field experiment was laid out in Randomized block design with nine treatments with three replications. The treatment comprises of nine fertility treatments viz. $\mathrm{T}_{1}-\mathrm{N} 0 \mathrm{P} 0$ - Control, $\mathrm{T}_{2-}$ N20 $\mathrm{P} 13$ - Fertilizer $\mathrm{N}$ and $\mathrm{P}$ at the rate of 20 and $13 \mathrm{Kg} \mathrm{ha}^{-1}, \mathrm{~T}_{3-}$ N30 P20 -Fertilizer N and P at the rate of 30 and $20 \mathrm{Kg} \mathrm{ha}^{-1}, \mathrm{~T}_{4-}$ N40 P26 Fertilizer $\mathrm{N}$ and $\mathrm{P}$ at the rate of 40 and $26 \mathrm{Kg}$ ha $^{-1}, \mathrm{~T}_{5-}$ N60 P35 - Fertilizer N and P at the rate of 60 and $35 \mathrm{Kg} \mathrm{ha}^{-1}, \mathrm{~T}_{6^{-}}$FYM $6 \mathrm{t} \mathrm{ha}^{-1}+$ $\mathrm{N}_{20} \mathrm{P}_{13}$ - Farmyard manure was applied @6t $\mathrm{ha}^{-1}$ prior to sowing of soybean plus fertilizer $\mathrm{N}$ and $\mathrm{P} @ 20$ and $13 \mathrm{Kg} \mathrm{ha}^{-1}, \mathrm{~T}_{7}$ - Residues 5t $\mathrm{ha}^{-1}+\mathrm{N}_{20} \mathrm{P}_{13}-$ Crop residues of soybean @ 5t $\mathrm{ha}^{-1}$ as surface mulch in between Crop rows + fertilizer $\mathrm{N}$ and $\mathrm{P}$ at the rate of 20 and $13 \mathrm{Kg}$ $\mathrm{ha}^{-1}, \mathrm{~T}_{8}$. FYM 6tha ${ }^{-1}$ - Farmyard manure alone @ 6t ha ${ }^{-1}, \mathrm{~T}_{9 .}$ Residues 5t ha ${ }^{-1}$-Soybean crop residues alone@5t ha ${ }^{-1}$ after emergence in between crops rows as surface mulch. The gross plot size was $10 \mathrm{~m} \times 7.2 \mathrm{~m}$ and after leaving non-experimental margin on both sides, the net experimental plot size was $9.0 \mathrm{~m}$ x $6.6 \mathrm{~m}$. Chickpea (Cicer arietinum L.) crop (JG-412) was sown on October 16, 2011 and harvested on February 07, 2012. Chickpea seed at the rate of $80 \mathrm{~kg}$ per hectare were sown at row-to-row distance of $30 \mathrm{~cm}$ and plant to plant distance of about $3 \mathrm{~cm}$ at 2 to $3 \mathrm{~cm}$ deep in soil.
The results obtained in this study as elucidated in chapter IV lead to the following conclusions:-Growth parameters and yield attributing characters of chickpea were improved significantly by the use of organics and $50 \%$ of recommended dose of chemical fertilizer. Root length was affected by fertility treatments It was higher in INM treatments Like T6- FYM 6t ha ${ }^{-1}+\mathrm{N}_{20} \mathrm{P}_{13}$, T7- Residues 5t $\mathrm{ha}^{-1}+\mathrm{N}_{20} \mathrm{P}_{13}$ as well as organic treatments as compeered to inorganic fertilizer application. Lowest root length was recorded in control.

The highest chickpea seed yield was recorded due to half of the recommended dose of $\mathrm{N}$ and $\mathrm{P}+6 \mathrm{tha}^{-1}$ of FYM (T6: FYM $\left.6 \mathrm{t} \mathrm{ha}^{-1}+\mathrm{T} 2\right)$, Treatments T4, T5 and T6 were at par among themselves and Treatment T6 was found superior to rest of the treatments. The treatment $\mathrm{T} 1$ i.e. control was found statistically inferior to all the treatments. The highest Gross and net return was obtained due to INM treatment followed by RDF, pure organic and lowest in case of control.

There was a non-significant difference in the $\mathrm{B}$ : $\mathrm{C}$ ratio of the treatments $\mathrm{T} 2, \mathrm{~T} 4, \mathrm{~T} 5$ and T6, Lowest B; C ratio was observed in Control treatment. FYM and crop residue added treatments gave higher MWD in comparison to chemical fertilizer added treatment. Addition of organic along with chemical fertilizer and alone reduced the bulk density. The porosity was highest in the treatment T6 $\left(\mathrm{FYM}+\mathrm{N}_{20} \mathrm{P}_{13}\right)$ and lowest in case of control. The application of organic manure considerably decreases the penetration force. Three is a marked difference in the initial infiltration rate of different treatments this difference was persisted till 9 hours of elapse time, but the magnitude of difference was reduced with time. Treatments involving FYM and crop residue resulted in a considerable buildup of soil fertility particularly available $\mathrm{N}, \mathrm{P}$ and organic carbon content in plough layer. 


\section{Nine treatments given to Chickpea crop}

\begin{tabular}{|c|c|c|c|}
\hline $\mathrm{T}_{1}$ & $\mathrm{~N}_{0} \mathrm{P}_{0}$ & - & Control i.e. no fertilizer from any source \\
\hline $\mathrm{T}_{2}$ & $\mathrm{~N}_{20} \mathrm{P}_{13}$ & - & Fertilizer N and P @ of 20 and $13 \mathrm{~kg} \mathrm{ha}^{-1}$ \\
\hline $\mathrm{T}_{3}$ & $\mathrm{~N}_{30} \mathrm{P}_{20}$ & - & Fertilizer N and P @ of 30 and $20 \mathrm{~kg} \mathrm{ha}^{-1}$ \\
\hline $\mathrm{T}_{4}$ & $\mathrm{~N}_{40} \mathrm{P}_{26}$ & - & Fertilizer N and P @ of 40 and $26 \mathrm{~kg} \mathrm{ha}^{-1}$ \\
\hline $\mathrm{T}_{5}$ & $\mathrm{~N}_{60} \mathrm{P}_{35}$ & - & Fertilizer N and P @ of 60 and $35 \mathrm{~kg} \mathrm{ha}^{-1}$ \\
\hline $\mathrm{T}_{6}$ & FYM $6 \mathrm{t}+\mathrm{N}_{20} \mathrm{P}_{13}$ & - & $\begin{array}{l}\text { Farmyard manure @6 t/ha in rainy season only + fertilizer } \mathrm{N} \text { and } \mathrm{P} \\
\qquad 20 \text { and } 13 \mathrm{~kg} \mathrm{ha}^{-1}\end{array}$ \\
\hline $\mathrm{T}_{7}$ & Residues $5 \mathrm{t}+\mathrm{N}_{20} \mathrm{P}_{13}$ & - & $\begin{array}{l}\text { Crop residues of soybean @ } 5 \mathrm{t} \mathrm{ha}^{-1} \text { as surface mulch in between } \\
\text { crop rows + fertilizer N and P @ of } 20 \text { and } 13 \mathrm{~kg} \mathrm{ha}^{-1}\end{array}$ \\
\hline $\mathrm{T}_{8}$ & FYM $6 \mathrm{t} \mathrm{ha}^{-1}$ & - & Farmyard manure@6 $\mathrm{tha}^{-1}$ in rainy season \\
\hline $\mathrm{T}_{9}$ & Residues $5 \mathrm{t} \mathrm{ha}^{-1}$ & - & $\begin{array}{c}\text { Crop residues of soybean @ } 5 \mathrm{t} \mathrm{ha}^{-1} \text { after emergence in between } \\
\text { crop rows as surface mulch }\end{array}$ \\
\hline
\end{tabular}

\section{Physio-chemical properties of the soil of the experimental field}

\begin{tabular}{|c|c|c|c|c|c|}
\hline SN & \multicolumn{3}{|c|}{ Soil parameters } & Value & Methods used \\
\hline \multirow[t]{4}{*}{1} & \multicolumn{2}{|r|}{ Mechanical composition } & & & \\
\hline & \multicolumn{2}{|r|}{ Sand \% } & & 13.25 & International Pipette method \\
\hline & \multicolumn{2}{|r|}{ Silt \% } & & 30.75 & - do - \\
\hline & \multicolumn{2}{|r|}{ Clay \% } & & 56.00 & - do - \\
\hline 2 & \multicolumn{2}{|r|}{ Soil pH (1: 2) } & & 7.6 & Glass electrode $\mathrm{pH}$ meter \\
\hline 3 & \multicolumn{2}{|c|}{$\begin{array}{l}\text { Electrical conductivity }\left(\mathrm{dSm}^{-1}\right)(1: \\
2 \text { soil/water ratio) }\end{array}$} & & 0.22 & (Piper, 1950) \\
\hline 4 & \multicolumn{2}{|r|}{ Organic carbon $(\%)$} & $0-30 \mathrm{~cm}$ & 0.38 & Walkley and Black method (1934) \\
\hline 5 & \multicolumn{2}{|r|}{ Calcium carbonate $(\%)$} & & 4.00 & \\
\hline 6 & \multicolumn{2}{|r|}{ Terminal infiltration rate } & & $10 \mathrm{~mm}$ & Infiltrometer Ring method (Richards, 1954) \\
\hline \multirow[t]{2}{*}{7} & \multirow{2}{*}{\multicolumn{2}{|c|}{ Moisture retention }} & $\begin{array}{l}\text { At } 0.3 \\
\text { bar }\end{array}$ & $400 \mathrm{~mm} \mathrm{~m}^{-1}$ & $\begin{array}{l}\text { Pressure plate and Pressure membrane apparatus } \\
\text { (Richards, 1954) }\end{array}$ \\
\hline & & & $\begin{array}{l}\text { At } 15 \\
\text { bar }\end{array}$ & $220 \mathrm{~mm} \mathrm{~m}^{-1}$ & \\
\hline \multirow[t]{5}{*}{8} & \multicolumn{2}{|r|}{ Available nutrient status } & & & \\
\hline & (i) & $\begin{array}{l}\text { Available nitrogen }(\mathrm{kg} \\
\left.\qquad \mathrm{N} \mathrm{ha}^{-1}\right)\end{array}$ & $0-30 \mathrm{~cm}$ & 180.13 & $\begin{array}{l}\text { Alkaline Permanganate method (Subbiah and Asija, } \\
1965)\end{array}$ \\
\hline & ii) & $\begin{array}{l}\text { Available phosphorus (kg } \\
\left.\qquad \mathrm{P} \mathrm{ha}^{-1}\right)\end{array}$ & $0-30 \mathrm{~cm}$ & 5.98 & $\begin{array}{l}\text { Spectro Photometer with Olsen's extractant (Olsen et } \\
\text { al., 1954) }\end{array}$ \\
\hline & iii) & $\begin{array}{l}\text { Available potassium }(\mathrm{kg} \\
\left.\qquad \mathrm{K} \mathrm{ha}^{-1}\right)\end{array}$ & $0-30 \mathrm{~cm}$ & 332.31 & Flame Photometer (Jackson, 1967) \\
\hline & iv) & $\begin{array}{l}\text { Available sulphur }(\mathrm{kg} \\
\left.\qquad \mathrm{S} \mathrm{ha}^{-1}\right)\end{array}$ & $0-30 \mathrm{~cm}$ & 12.58 & Bardsley and Lancastor method (1960). \\
\hline
\end{tabular}

Table.1 Plant growth and yield attributing characters of chickpea as influenced by different treatments at harvest (2011-12)

\begin{tabular}{|c|c|c|c|c|c|c|}
\hline TREATMENTS & $\begin{array}{l}\text { Plant height } \\
(\mathrm{cm})\end{array}$ & $\begin{array}{c}\text { Branch } \\
\text { plant }^{-1}\end{array}$ & $\begin{array}{l}\text { Pods } \\
\text { plant }^{-1}\end{array}$ & $\begin{array}{c}\text { TDM } \\
\text { plant }^{-1}(\mathrm{~g})\end{array}$ & $\begin{array}{c}\text { Yield } \\
\text { plant }^{-1}(\mathrm{~g})\end{array}$ & $\begin{array}{c}\text { Test } \\
\text { wt.(g) }\end{array}$ \\
\hline T1-N0 P0- Control & 36.67 & 3.60 & 33.20 & 14.1 & 6.6 & 15.53 \\
\hline T2- N20 P13 & 41.93 & 3.07 & 33.73 & 19.4 & 8.9 & 16.83 \\
\hline T3-N30 P20 & 44.33 & 3.60 & 41.47 & 20.2 & 10.3 & 16.90 \\
\hline T4-N40 P26- & 47.80 & 3.53 & 41.13 & 21.9 & 11.2 & 17.87 \\
\hline T5-N60 P35 & 49.03 & 3.27 & 43.67 & 24.7 & 11.9 & 17.73 \\
\hline T6- FYM $6 \mathrm{t} \mathrm{ha}^{-1}+\mathrm{T} 2$ & 52.80 & 4.13 & 48.13 & 24.1 & 12.6 & 17.80 \\
\hline T7-Residues $5 \mathrm{t} \mathrm{ha}^{-1}+\mathrm{T} 2$ & 49.90 & 2.93 & 47.47 & 20.7 & 11.0 & 17.43 \\
\hline T8-FYM 6t ha & 44.00 & 3.87 & 43.73 & 23.3 & 12.0 & 17.67 \\
\hline T9 -Residues 5t ha ${ }^{-1}$ & 47.53 & 3.47 & 41.73 & 21.9 & 11.0 & 17.40 \\
\hline $\mathrm{SEm} \pm$ & 3.4 & 0.44 & 3.87 & 1.7 & 0.9 & 0.40 \\
\hline CD $5 \%$ & 10.1 & 1.31 & 11.61 & 5.2 & 2.7 & 1.20 \\
\hline
\end{tabular}


Table.2 Seed and straw yield, harvest index and economics of chickpea production due to different treatments $\left(\mathrm{kg} \mathrm{plot}^{-1}\right)$

\begin{tabular}{|c|c|c|c|c|c|}
\hline Treatments & $\begin{array}{c}\text { Seed yield } \\
\left(\mathrm{kg} \mathrm{ha}^{-1}\right)\end{array}$ & $\begin{array}{c}\text { Straw } \\
\text { yield } \\
\left(\mathrm{kg} \mathrm{ha}^{-1}\right)\end{array}$ & $\underset{\%}{\text { HI }}$ & $\begin{array}{l}\text { Net returns } \\
\left(\text { Rs ha }^{-1}\right)\end{array}$ & $\begin{array}{l}\mathrm{BC} \\
\text { ratio }\end{array}$ \\
\hline T1 Control & 566 & 592 & 49.6 & 12122 & 2.15 \\
\hline T2 N20 P13 & 762 & 684 & 52.7 & 19307 & 2.73 \\
\hline T3 N30 P20 & 999 & 737 & 57.6 & 28476 & 3.48 \\
\hline T4 N40 P26 & 1044 & 779 & 57.2 & 29905 & 3.52 \\
\hline T5 N60 P35 & 1211 & 930 & 57.1 & 35893 & 3.86 \\
\hline T6 FYM 6 tha $^{-1}+$ T2 & 1372 & 1001 & 57.7 & 44594 & 5.34 \\
\hline T7 Residues 5 tha $^{-1}+\mathrm{T} 2$ & 1258 & 941 & 56.4 & 38831 & 4.38 \\
\hline T8 FYM 6 tha $^{-1}$ & 1052 & 858 & 54.9 & 31978 & 4.17 \\
\hline T9 Residues 5 tha $^{-1}$ & 1020 & 803 & 55.6 & 30291 & 3.88 \\
\hline SEm \pm & 94 & 75.6 & & 4161 & 1.02 \\
\hline $\mathrm{CD}(5 \%)$ & 281 & 160 & & 1577 & 15.79 \\
\hline
\end{tabular}

The percent increase in organic carbon, $\mathrm{N}, \mathrm{P}$, $\mathrm{K}$ and $\mathrm{S}$ was $154 \%, 58 \%, 107 \%, 53 \%$ and $171 \%$, respectively due to treatments $\mathrm{T} 6$ over control. Addition of organics and RDF has helped to build up soil fertility but lower doses of $\mathrm{N}$ and $\mathrm{P}$ as compared to $\mathrm{RDF}$ has depleted the soil fertility in terms of OC, N, P, $\mathrm{K}$ and $\mathrm{S}$ content. The perusal of the data revealed that $\mathrm{OC}$ balance was found negative in the treatment $\mathrm{T} 1, \mathrm{~T} 2$, and $\mathrm{T} 3$. The highest buildup of OC was obtained in T6- FYM $6 \mathrm{t}$ $\mathrm{ha}^{-1}+\mathrm{T} 2$ followed by T8-FYM 6t ha $\mathrm{h}^{-1}$, T7Residues $5 \mathrm{t} \mathrm{ha}^{-1}+\mathrm{T} 2$, T9 -Residues $5 \mathrm{t} \mathrm{ha}^{-1}$, T5-N60 P35 and T4-N40 P26. In case of nitrogen there was a negative balance in $\mathrm{T} 1$ (Control) and T2 treatments rest of the treatments have positive balance. The $\mathrm{P}$ and $\mathrm{K}$ balance was found +ve in all the treatments except T1 Control, where it was found -ve. S balance was found -ve balance in all the treatments. The soil quality assessment study on the basis of the criteria given by Pierce and Larson (1993) and Larson and Pierce (1994) conclude that there was a great increase in soil quality in the treatments T6, T7, T8 and T9 due to addition of organics, while this increase was moderate in the treatments $\mathrm{T} 3$, $\mathrm{T} 4$, and $\mathrm{T} 5$. The increase in soil quality in case of inorganic fertilization with $50 \%$ of RDF was slight. Treatment T6: FYM 6t ha ${ }^{-1}+$ $\mathrm{T} 2$ recorded higher uptake of $\mathrm{N}, \mathrm{P}, \mathrm{K}$ and $\mathrm{S}$ as compared to any level of application of fertilizer source. Lowest uptake of all the nutrients was recorded in the control i.e. T1. The WUE being lowest in T1: N0 P0 Control plots and highest in T6: FYM $6 \mathrm{t} \mathrm{ha}^{-1}+\mathrm{T} 2$.

\section{References}

Bardsley C.E. and T.D. Lancastor 1960. Determination of reserve sulphur and soluble sulphates in soils. Soil Sci. Soc. Am. Proc. 24:265-268

Karlen. D.L., M.I. Mauschbach; J.W. Doron; R.G. Cline; R.F. Harris and G.E. Sehuman 1997. Soil quality; A concept, Definition and a frame work evaluation. Soil.Sc.Soc.Amrican.J. 61.PP. 4-10.

Larson, W.E. and F.J. Pierce 1994. The dynamics of soil quality as a measure of sustainable management. In Defining Soil Quality for a sustainable environment. J.W. Doran. et al., (eds.). SSSA. Spec. Publ. 35, SSSA and ASA, Madison, WI. pp 37-51. 
Olsen C.V. Cole., F.S. Watanabe and L.A. Dean 1954. Estimation of available phosphorus in soil by extraction with sodium bicarbonate. USDA, Circ. 939.

Pierce, F.J. and W.E. Larson1993. Developing criteria to evaluate sustainable land management. In Utilization of Soil Survey Information for Sustainable land Use. Kimble (ed.). Proceeding of the eighth international soil management workshop: Oregone, California, and Nevada. May 1993. USDA, Soil Conservation Service, National Soil Survey Center, Licoin, NE. pp7-14.

Piper C.S. (1950). Soil and Plant analysis. Univ. of Adelaide, Australia.
Subbiah B.V. and G.L. Asija 1956. A rapid procedure for the determination of available nitrogen in soils. current Science, 25:259-260.

Virmani, S.M., P. Pathak and R. Singh. 1991. Soil related constraints in dryland crop production in Vertisoles, Alfisoles and Entisoles of India. In Soil related Constraints in crop production, $J$. Indian Soc. Soil Sci. New Delhi, India. pp. 80-95.

Walkley A. and C.A. Black 1934. An examination of the degtjareff method for determining the soil organic matter and a proposed modification of the chromic acid titration method. Soil Sci. 37: 29-38.

\section{How to cite this article:}

Patidar, P., S.P.K. Unni, S.K. Sharma and Khandkar, U.R. 2018. Assessment of Soil Quality and Performance of Chickpea under Permanent Manurial Trial on Soybean-Chickpea Sequence in Rainfed Vertisols. Int.J.Curr.Microbiol.App.Sci. 7(04): 1585-1590. doi: https://doi.org/10.20546/ijcmas.2018.704.178 